\title{
IMPLEMENTASI METODE PEMBELAJARAN SQ3R (SURVEY, QUESTION, READ, RECITE, REVIEW) DALAM UPAYA MENINGKATKAN HASIL BELAJAR BIOLOGI
}

\author{
Dasiti \\ Madrasah Aliyah Negeri 1 Kuningan, Jl. Mayasih No.881, Cigugur, Kuningan, Indonesia \\ Email: Itidasiti@gmail.com
}

\begin{abstract}
Basically, all of the children have the potential to achieve competence. Therefore, providing the students with the creative teacher is necessary. Utilized by the appropriate method, it enables the teacher to achieve the learning objective. Therefore, the writer has an effort to achieve the learning objective by applying the SQ3R learning method to improve the learning outcomes. This action research involves 33 students of Class $X$ - I MAN 1 Kuningan and employs several methods of data collection, namely, documentation, interviews, observation and tests. The action research model used is a spiral model adopted from Kemmis and Taggart which consists of two cycles at which each cycle consists of 4 stages including planning, implementing, acting, observing and reflecting. Based on the research results, it is found that there is an increase in students' learning outcomes indicated by the value of the discussion in cycle I with an average of 62.2 with $76.67 \%$ completeness of classical learning; then, it increases to 75.73 with $90.9 \%$ of classical learning completeness in cycle II. While the evaluation value with an average of 62.25 with $75.75 \%$ completeness classical learning increases to 76.30 with $93.93 \%$ classical learning completeness. Obstacles experienced in the learning process using the SQ3R learning method include students' low motivation to learn and limited books at school.
\end{abstract}

Keywords: SQ3R Learning Method, Learning Outcomes

\begin{abstract}
ABSTRAK
Pada dasarnya semua anak memiliki potensi untuk mencapai kompetensi sehingga perlu adanya kreatifitas guru untuk membantu mencapainya. Dengan memanfaatkan metode secara tepat guru akan mampu mencapai tujuan pengajaran. Oleh karena itu penulis menerapkan metode pembelajaran SQ3R sebagai upaya untuk meningkatkan hasil belajar. Subyek penelitian ini adalah peserta didik Kelas X - I MAN 1 Kuningan dengan jumlah peserta didik 33 orang. Dalam penelitian ini penulis menggunakan beberapa metode pengumpulan data, yaitu: dokumentasi, wawancara, observasi dan tes. Model penelitian tindakan kelas yang dilakukan dalam penelitian ini adalah model spiral dari Kemmis dan Taggart yang terdiri dari dua siklus tindakan dimana setiap siklus tersebut terdiri dari 4 tahapan yang meliputi perencanaan, pelaksanaan, tindakan, observasi dan refleksi. Berdasarkan hasil penelitian diperoleh hasil belajar peserta didik mengalami peningkatan yaitu dari nilai diskusi siklus I dengan rata-rata 62,2 dengan ketuntasan belajar klasikal 76,67\%, meningkat menjadi 75,73 dengan ketuntasan belajar klasikal 90,9\% pada siklus II. Sedangkan nilai evaluasi dengan rata-rata 62,25 dengan ketuntasan belajar klasikal 75,75\% meningkat menjadi 76,30 dengan ketuntasan belajar klasikal $93,93 \%$. Hambatan yang dialami dalam proses pembelajaran menggunakan metode pembelajaran SQ3R antara lain motivasi dari peserta didik untuk belajar masih tergolong rendah dan adanya keterbatasan buku di sekolah.
\end{abstract}

Kata Kunci: Metode Pembelajaran SQ3R, Hasil Belajar

Cara sitasi: Dasiti. (2021). Implementasi metode pembelajaran sq3r (survey, question, read, recite, review) dalam upaya meningkatkan hasil belajar biologi. J-KIP (Jurnal Keguruan dan IImu Pendidikan), 2 (2), 15-20. 


\section{PENDAHULUAN}

Sopiah menyatakan bahwa pendidikan merupakan hal penting dalam rangka meningkatkan kualitas Sumber Daya Manusia baik dari segi spiritual, intelegensi, maupun skill untuk menunjang kehidupannya (Herdiana, Zakiah \& Sunaryo: 2021 ). Dimyati \& Mudjiono (2006) menyatakan bahwa dalam teori kognitif belajar menunjukkan adanya jiwa yang aktif, jiwa mengolah informasi yang kita terima, tidak sekedar menyimpannya saja tanpa mengadakan transformasi. Hal ini sesuai dengan salah satu prinsip belajar adalah keaktifan. Belajar hanya dapat terjadi apabila peserta didik aktif mengalami sendiri. Dalam mewujudkan peserta didik aktif maka perlu adanya aktivitas belajar. Aktivitas belajar ini dapat terwujud jika peserta didik dihadapkan pada masalah. Belajar merupakan proses mencari ilmu yang terjadi dalam diri seseorang melalui latihan dan pembelajaran sehingga terjadi perubahan dalam diri sendiri. Untuk itu guru perlu meningkatkan mutu pembelajarannya sehingga hasil belajar yang dicapai dapat optimal.

Peserta didik hanya mungkin dapat belajar dengan baik manakala ada dalam suasana yang menyenangkan, merasa aman, bebas dari rasa takut. Oleh karena itu guru harus bisa menciptakan iklim belajar yang kondusif yang menyenangkan agar dapat membangkitkan semangat dan menumbuhkan aktivitas serta kreativitas peserta didik sehingga peserta didik lebih mudah dalam memahami materi pelajaran.

Metode adalah salah satu alat untuk mencapai tujuan. Dengan memanfaatkan metode secara tepat guru akan mampu mencapai tujuan pengajaran. Oleh karena itu guru harus bisa memilih metode pembelajaran sesuai dengan materi yang disampaikan. Aktivitas guru dan peserta didik sebagai pelaku utama dalam kegiatan belajar mengajar mutlak diperlukan demi tercapainya tujuan belajar.

Belajar bersama dalam kelompok adalah suatu cara yang dipakai untuk menyelenggarakan pembelajaran dalam bentuk kelompok belajar yang lebih kecil. Paserta didik dalam satu kelas dibagi menjadi beberapa kelompok belajar yang lebih kecil yang heterogen (campuran) dalam hal kemampuan intelektual, jenis kelamin, dan latar belakang budaya, sehingga terwujud kerjasama untuk saling membantu dalam memahami materi. Dipandang dari tingkat partisipasi aktif peserta didik, keuntungan belajar bersama secara kelompok mempunyai tingkat partisipasi aktif yang tinggi. Mengalami langsung apa yang sedang dipelajari akan mengaktifkan lebih banyak indera daripada hanya mendengarkan guru menerangkan. Pada dasarnya semua anak memiliki potensi untuk mencapai kompetensi sehingga perlu adanya kreatifitas guru untuk membantu mencapainya.

Untuk itu penulis menerapkan metode pembelajaran SQ3R. Penerapan metode ini diharapkan hasil pembelajaran peserta didik lebih memuaskan, karena peserta didik menjadi pembaca aktif dan terarah langsung pada kandungan pokok dalam teks (Hanafiah, 2009). Metode belajar tersebut adalah cara mempelajari teks (bacaan) kususnya yang terdapat dalam buku, artiket ilmiah, dan laporan penelitian. Peserta didik akan mudah mengingat materi, karena peserta didik belajar secara berkelompok dan diberi kesempatan lebih aktif mencari serta memahami materi dari teks atau buku sehingga terdapat peluang lebih besar untuk meningkatkan hasil belajar biologi pada materi pokok sistem pencernaan makanan. Suprijono (2009) menyatakan bahwa langkah pertama survey, yaitu membantu dan mendorong siswa untuk memeriksa atau meneliti secara singkat seluruh struktur teks. Langkah kedua yaitu question yaitu memberi petunjuk atau contoh kepada para siswa untuk menyusun pertanyaan- pertanyaan yang jelas, singkat dan relevan dengan bagianbagian teks yang telah ditandai pada langkah pertama. Langkah ketiga read yaitu menyuruh siswa membaca secara aktif dalam rangka mencari jawaban atas pertanyaan- pertanyaan yang telah tersusun. Langkah keempat recite, yaitu menyuruh siswa untuk menyebutkan lagi jawaban-jawaban atas pertanyaan yang telah tersusun. Dalam kesempatan ini siswa dilatih untuk tidak membuka catatan jawaban. Langkah terakhir review, yaitu menyuruh siswa meninjau ulang seluruh pertanyaan dan jawaban secara singkat dengan menerapkan metode SQ3R pada proses belajar mengajar. 
Dari uraian yang telah dipaparkan maka tujuan dari penelitian ini adalah mengetahui imlplementasi metode pembelajaran SQ3R dapat meningkatkan hasil belajar biologi di MAN 1 Kuningan materi pokok sistem pencernaan makanan dan mengetahui hambatan implementasi metode pembelajaran SQ3R terhadap hasil belajar biologi di MAN 1 Kuningan.

\section{METODE PENELITIAN}

Subyek penelitian ini adalah peserta didik Kelas X - I MAN 1 Kuningan dengan jumlah peserta didik 33 orang dengan komposisi 11 anak laki-laki dan 22 anak perempuan. Pada penelitian ini, yang menjadi kolaborator adalah guru mata pelajaran biologi Kelas X - I IPA di MAN 1 Kuningan. Dalam penelitian ini penulis menggunakan beberapa metode yaitu: dokumentasi, wawancara, observasi dan tes.

Model penelitian tindakan yang dilakukan dalam penelitian ini adalah model spiral dari Kemmis dan Taggart yang terdiri dari beberapa siklus tindakan. Dimana setiap siklus tersebut terdiri 4 tahapan yang meliputi perencanaan, pelaksanaan tindakan, observasi dan refleksi.

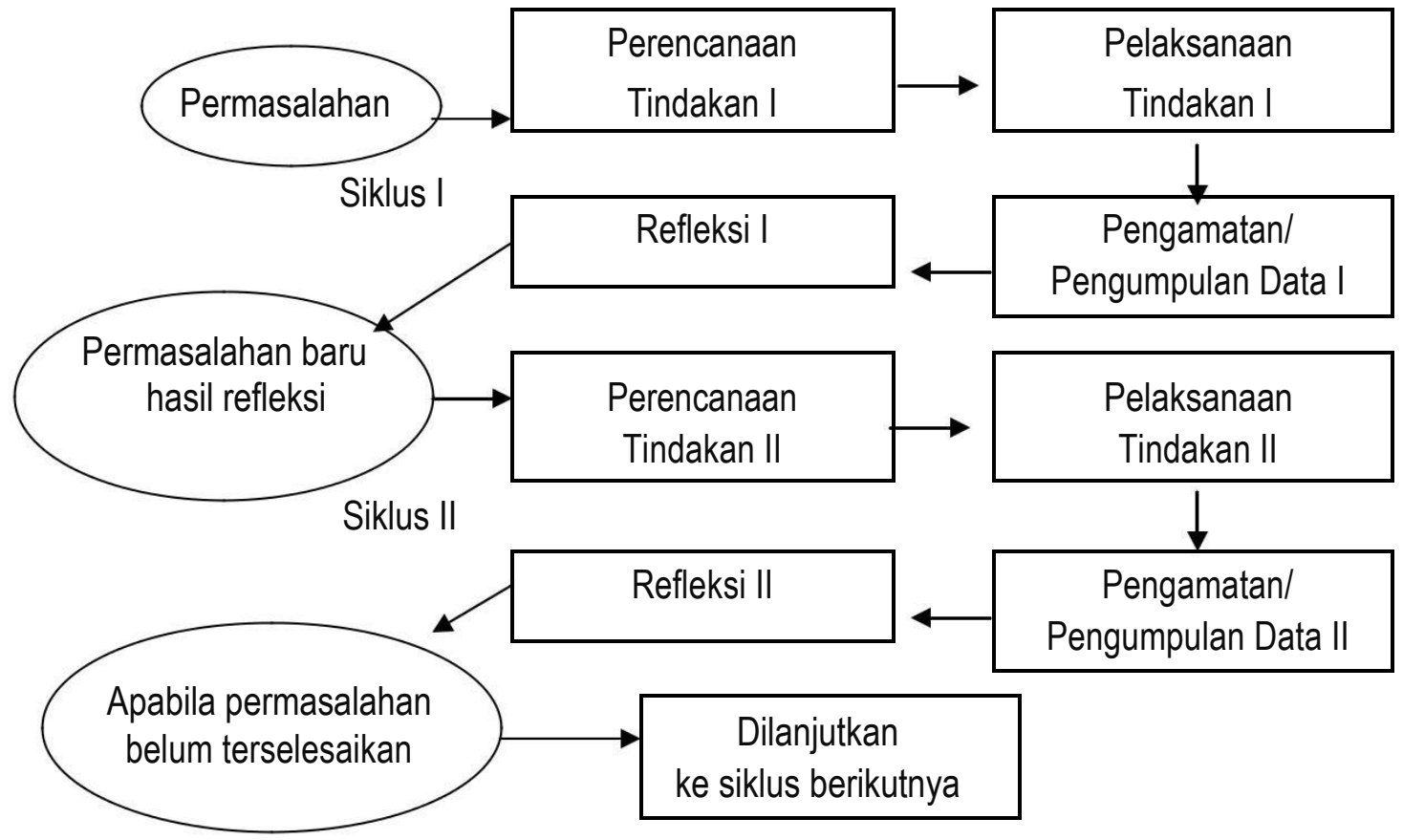

Gambar 1. Siklus penelitian tindakan kelas (PTK)

Sebagai indikator keberhasilan dari penelitian tindakan kelas ini adalah jika 85\% peserta didik telah memperoleh nilai minimal 62 (sesuai ketentuan KKM dari sekolah). Seorang peserta didik dikatakan telah mencapai ketuntasan belajar secara individu apabila peserta didik tersebut telah mencapai ketentuan belajar secara individual dan mendapat nilai $\geq 62$ (sesuai ketentuan dari sekolah). Dari indikator tersebut, maka peneliti berharap agar hasil belajar biologi peserta didik dapat mengalami peningkatan setelah dilakukan tindakan. Dengan adanya peningkatan prosentase hasil belajar biologi peserta didik menjadi $85 \%$, khususnya pada materi pokok sistem pencernaan manusia.

\section{HASIL DAN PEMBAHASAN}

\section{Implementasi metode pembelajaran SQ3R}

Siklus I

Siklus ini dilaksanakan pada tanggal 10 Februari 2017 (11.00 s.d 12.45 WIB) dan tanggal 11 Februari 2017 (8.30 s.d 10.15 WIB). Dari pengamatan siklus I diperoleh temuan antara lain guru 
dalam melaksanakan penerapan "Metode pembelajaran SQ3R" diawali dengan tahap pemberian apersepsi terhadap materi di kelas dengan metode konvensional, kemudian membagi kelompok dan selanjutnya pesera didik melaksanakan proses pembelajaran mengunakan metode SQ3R akan tetapi pengelolaan waktu kegiatan pembelajaran kurang baik terlihat molornya waktu diskusi kelompok kecil sehingga waktu presentasi singkat. Selain itu juga dalam memberikan motivasi dan bimbingan terhadap peserta didik baik dalam kelompok maupun individu kurang merata sehingga ada beberapa peserta didik yang merasa kesulitan dalam menyelesaikan pemecahan soal diskusi yang diberikan.

\section{Siklus II}

Siklus II dilaksanakan tiga pertemuan, empat jam pelajaran yaitu pada tanggal 17 Februari 2017 (12.00 s.d 12. 45 WIB), 18 Februari 2017 (08.30 s.d 10.15 WIB) dan 24 Februari 2010 (11.00 s.d 11.45 WIB). Berdasarkan refleksi pada siklus I, pelaksanaan tindakan pada siklus II oleh guru sudah baik dengan bukti pengelolaan waktu yang sudah sesuai dengan rencana pembelajaran dan pemberian semangat oleh guru kepada peserta didik sudah merata. Disamping itu, peserta didik juga sudah mampu melaksanakan tahapan-tahapan "Metode pembelajaran SQ3R" dengan baik. Terbukti dengan adanya pencarian referensi yang dilakukan peserta didik, diskusi kelompok kecil yang berjalan lancar, presentasi yang cukup memuaskan serta mampu menyelesaikan soal evaluasi

\section{Hasil belajar}

Dari nilai diskusi peserta didik dalam proses pembelajaran mengunakan metode SQ3R mengalami peningkatan. Hal ini terbukti dengan peningkatan ketuntasan belajar klasikal pada nilai diskusi dari $76,67 \%$ pada siklus I menjadi $90,9 \%$ disiklus II. Serta ketuntasan belajar klasikal pada nilai evalusi dari $75,75 \%$ pada siklus I menjadi $93,93 \%$ pada siklus II. Peningkatan ketuntasan belajar nilai diskusi, dengan ketuntasan belajar nilai evaluasi dalam pembelajaran dari siklus I ke siklus II dapat dilihat pada histogram dibawah ini:

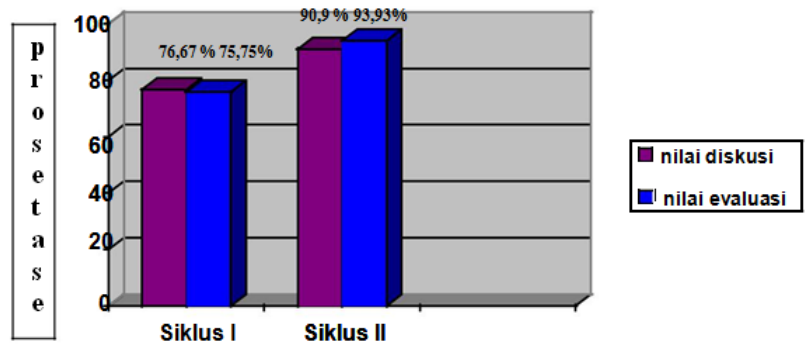

\section{Gambar 1. Histogram ketuntasan belajar dari nilai diskusi Peserta didik dan ketuntasan belajar dari nilai evaluasi peserta didik}

Selain peningkatan yang terjadi terhadap ketuntasan belajar dari nilai diskusi peserta didik dan ketuntasan belajar dari nilai evaluasi peserta didik, dalam penelitian ini juga terjadi peningkatan terhadap rata-rata hasil belajar peserta didik. Dengan bukti jika dalam siklis I nilai rata-rata kelas pada nilai diskusi 62,2 pada siklus II mengalami peningkatan yaitu 75,72 . Sedangkan nilai rata-rata evaluasi siklus I 66,25 mengalami peningkatan menjadi 76,30. Dapat dituliskan dalam Tabel 1.

Tabel 1. Nilai rata-rata kelas pada nilai diskusi dan nilai evaluasi siklus I dan siklus II

\begin{tabular}{lll}
\hline Rata-rata & Siklus I & Siklus II \\
\hline Nilai diskusi & 62,2 & 75,72 \\
Nilai evaluasi & 66,25 & 76,72 \\
\hline
\end{tabular}




\section{Hambatan implementasi SQ3R terhadap hasil belajar}

Metode pembelajaran SQ3R lebih mengutamakan keaktifan dan kreatifitas peserta didik, baik dari mencari sumber/referensi materi, menjawab pertanyaan peneliti yang dihadapkan pada kemampuan memadukan beberapa pemikiran atau argumen dari peserta didik dalam kelompok, ketelitian membaca serta kreatifitas dalam menyampaikan atau presentasi didepan kelas. Tentunya akan menimbulkan beberapa hambatan apabila peserta didik tidak mampu diajak kerjasama untuk lebik aktif daripada sekedar menunggu diterangkan guru. Kelebihan penggunaan metode akan menjadi sebuah hambatan tanpa adanya motivasi dari diri peserta didik dan guru untuk menciptakan suasana kelas yang menyenangkan dan kooperatif. Hambatan yang terjadi pada siklus I sudah mampu diminimalisir tetapi hambatan yang masih dirasakan dalam siklus II adalah kurangnya sumber bacaan yang tersedia disekolah, motivasi dari peserta didik untuk belajar masih tergolong rendah apalagi ketika guru tidak mampu bersikap tegas dalam pembelajaran maupun pemberian nilai hal tersebut akan sedikit demi sedikit mengalami perubahan apabila mulai didukung dari berbagai pihak yaitu keluarga dan sekolah.

Hasil penelitian ini sejalan dengan hasil penelitian Syamsiah, Adnan \& Suhriana (2012) yang menyatakan bahwa 1) penerapan metode SQ3R (Survey, Question, Read, Recite, Review) dapat meningkatkan aktivitas belajar biologi pada konsep sistem pencernaan manusia pada siswa kelas VIIIA SMP Negeri 1 Lamuru; 2) penerapan metode SQ3R (Survey, Question, Read, Recite, Review) dapat meningkatkan hasil belajar biologi pada konsep sistem pencernaan manusia pada siswa kelas VIIIA SMP Negeri 1 Lamuru. Senada juga dengan pendapat dari Trianto (2009) bahwa penerapan metode SQ3R akan memberikan manfaat bagi guru dan siswa yakni lebih mudah menguasai kelas, lebih melibatkan siswa secara langsung dan aktif dalam proses belajar mengajar dan akan memperkuat daya ingat siswa.

\section{KESIMPULAN}

Berdasarkan hasil penelitian yang penulis lakukan tentang penerapan metode pembelajaran SQ3R (Survey, Question, Read, Recite, Review) sebagai salah satu upaya dalam meningkatkan hasil belajar pada materi pokok sistem pencernaan manusia di MAN 1 Kuningan, dapat diambil kesimpulan bahwa:

1. Hasil belajar peserta didik dengan penerapan metode pembelajaran SQ3R (Survey, Question, Read, Recite, Review) khususnya pada materi pokok sistem pencernaan manusia mengalami peningkatan yaitu dari nilai diskusi siklus I dengan rata-rata 62,2 dengan ketuntasan belajar klasikal (seluruh peserta didik) 76,67\%, meningkat menjadi 75,73 dengan ketuntasan belajar klasikal (seluruh peserta didik) 90,9\% pada siklus II. Sedangkan nilai evaluasi dengan rata-rata 62,25 dengan ketuntasan belajar klasikal (seluruh peserta didik) $75,75 \%$ meningkat menjadi 76,30 dengan ketuntasan belajar klasikal (seluruh peserta didik) 93,93\%. Maksudnya, pada siklus I, ada 7 peserta didik yang tidak tuntas dalam nilai diskusi serta 8 peserta didik yang memperoleh nilai evaluasi di bawah KKM (62), sedangkan pada siklus II, hanya ada 3 peserta didik tidak tuntas nilai diskusi dan 2 peserta didik yang nilai evaluasinya di bawah KKM.

2. Hambatan yang dialami dalam proses pembelajaran menggunakan metode pembelajaran SQ3R (Survey, Question, Read, Recite, Review) untuk meningkatkan hasil belajar pada materi sistem pencernaan makanan manusia antara lain :

a. Motivasi dari peserta didik untuk belajar masih tergolong rendah apalagi ketika guru tidak mampu bersikap tegas dalam pembelajaran maupun pemberian nilai hal tersebut akan sedikit demi sedikit mengalami perubahan apabila mulai didukung dari berbagai pihak yaitu keluarga dan sekolah.

b. Adanya keterbatasan buku disekolah, walaupun didukung referensi dari internet, tetapi tanpa adanya kreatifitas peserta didik untuk mencari sumber materi dari tempat lain, juga akan 
menjadi hambatan terlaksananya pembelajaran dengan metode SQ3R sehingga hasil belajar tidak mencapai indikator yaitu nilai 62 (sesuai KKM).

\section{REKOMENDASI}

Sebaiknya guru selalu berusaha untuk membimbing kegiatan peserta didik dalam kerja kelompok agar setiap peserta didik tidak saling menggantungkan diri dengan peserta didik yang lain dan benar-benar dapat bekerjasama dengan anggota kelompoknya sehingga ketika mengerjakan tugas dengan kerja kelompok ataupun sedang berdiskusi, setiap peserta didik turut aktif dan mengutarakan pendapat di dalam kelompok mereka.

\section{UCAPAN TERIMA KASIH}

Penulis mengucapan terima kasih kepada peserta didik Kelas X - I MAN 1 Kuningan dengan jumlah peserta didik 33 orang dengan komposisi 11 anak laki-laki dan 22 anak perempuan. Selanjutnya penulis mengucapkan terima kasih kepada kolaborator yaitu guru mata pelajaran biologi Kelas X - I IPA di MAN 1 Kuningan.

\section{DAFTAR PUSTAKA}

Dimyati \& Mudjiono. (2006). Belajar dan pembelajaran. Jakarta: Rineka Cipta.

Hanafiah \& Suhana C. (2009). Konsep strategi pembelajaran. Bandung : Refika Aditama.

Herdiana, L., Zakiah, N. E., \& Sunaryo, Y. (2021). Penerapan Model Pembelajaran Diskursus Multy Reprecentacy (DMR) terhadap Kemampuan Pemahaman Matematis Siswa. J-KIP (Jurnal Keguruan dan IImu Pendidikan), 2 (1), 9-14.

Suprijono, A. (2009). Cooperative learning teori dan aplikasi paikem. Yogyakarta : Pustaka Belajar..

Syamsiah., Adnan., \& Suhriana. (2012). Penerapan metode sq3r (survey, question, read, recite, review) untuk meningkatkan aktivitas dan hasil belajar biologi siswa kelas viiia smp negeri 1 lamuru kabupaten bone. Jurnal Sainsmat, I(1), 100-108.

Trianto. (2009). Mendesain model pembelajaran inovatif progresif: konsep, landasan dan implementasinya pada kurikulum tingkat satuan pendidikan (ktsp). Jakarta: Kencana. 